\title{
CREB-Regulated Transcription Coactivator 3
}

National Cancer Institute

\section{Source}

National Cancer Institute. CREB-Regulated Transcription Coactivator 3. NCI Thesaurus. Code C95279.

CREB-regulated transcription coactivator 3 (619 aa, $\sim 67 \mathrm{kDa}$ ) is encoded by the human CRT C3 gene. This protein is involved in the positive regulation of transcription. 